\title{
AN INVESTIGATION ON THE TRANSACTION MOTIVATION AND THE SPECULATIVE MOTIVATION OF THE DEMAND FOR MONEY IN SRI LANKA
}

\author{
S.N.K. Mallikahewa \\ Senior Lecturer, Department of Economics, University of Colombo, Sri Lanka. \\ H. Nadeeka De Silva \\ Assistant Lecturer, Department of Management, South Eastern University of Sri Lanka.
}

\begin{abstract}
The main objective of this study is to empirically investigate the transaction (income elasticity) and speculative motivations (interest rate elasticity) of the demand for money in the Sri Lankan context and to examine its stability. The study employed the use of co-integration test over the 1977 to 2009, to estimate long run relationship between money demand and its determinants: real income and interest rate. The study found out that money demand function is stable in Sri Lanka for the sample period. The income is the most significant factor of the demand for money, and it makes a powerful positive impact on real money demand. Interest rate is positively related with real money demand and significant, but not consistent with existing theories. Demand for Money on transaction motivation is larger than its speculative motivation in the Sri Lankan context.
\end{abstract}

Key words: Real Money Balance, Income Elasticity, Interest Elasticity, Transaction Motivation, Speculative Motivation, Co-integration Methodology

\section{Introduction}

The importance of the demand for money has become a prominent research topic in economics due to its role in monetary policy formulation. Income elasticity and interest elasticity of money demand affect the channels of the transmission mechanism ${ }^{3}$ of monetary policy. Empirical interest in demand for money functions arises because a stable and predictable money demand function is a pre-requisite for the use of targets for monetary aggregates as an objective of monetary policy. Interest elasticity of such functions is crucial for the relative effectiveness of monetary and fiscal policy. (McMorrow, 1998).

Among developing countries, it is accepted that interest rate is an unsatisfactory measure of the opportunity cost of holding money. First, financial markets have not well developed in the developing countries, and due to this situation, possibilities of substitution between money and other financial assets are limited. Secondly, a more practical objection is that the interest rates are often determined by the government and remain constant for long periods, and there wouldn't be sufficient variation to enable its influence on the demand for money. As a developing country, Sri Lanka has experiences of low economic growth with high inflation for a long time period. (Central Bank Reports. Sri Lanka). There is a research space to examine whether interest rate transmission mechanism is effective in the Sri Lankan context. For the good performance of interest rate transmission mechanism, interest rate elasticity of money demand function is crucial.

\section{Theoretical and empirical background}

The Theory of demand for money called that the liquidity preference theory hypothesized by John Maynard Keynes' (1936), describes that why people hold money. Keynes postulated that 
there are three purposes for holding money by adding the precautionary and asset (speculative) motives to the classical transactions motive. Keynes also took the transactions component of the demand for money to be proportional to income because like classical economist he believed that these transactions are proportional to income. (Mishkin,2004).

In addition to holding money to meet current transactions, people hold money as a cushion against an unexpected need. Keynes suggested that the amount of money balances for precautionary purpose that people want to hold is determined by the level of transactions that they expect to make in the future and that these transactions are proportional to income. Therefore, Keynes (1936) emphasized that the demand for precautionary money balances is proportional to income.

$$
\text { M1 }=\text { MT }+ \text { MP }=\mathbf{L 1}(\mathbf{P Y})=\mathbf{L 1}(\mathbf{Y})
$$

Where,

M1 - Money demand on both transactionsmotive and the precautionary-motive

MT - Money demand on transactions-motive

MP - Money demand on precautionary-motive

L1 - functional tendency, which fixes the quantity of money which the people willing to hold money on both transactions-motive and the precautionary-motive

PY - Nominal income (Y)

Keynes considered the view that money as a store of wealth and called this reason for holding money the speculative motive. Keynes analyses the factors that affect the decisions regarding how much money to hold as a store of wealth: especially interest rates.

Various financial assets except money, gain a positive interest rate plus a capital gain. According to Keynes, long term government bonds are the only alternative monetary assets for money asset. People have to make choice between government bonds ${ }^{9}$ and money. If expected return of holding money is greater than the expected return from holding bonds, individuals decide to hold their wealth in the form of money rather than bonds. The expected return in holding money is zero because in Keynes' view money is the most liquid asset and through holding that asset in hand no one can earn interest. But for the bonds have positive expected returns or negative expected returns.

If people expect interest rates to rise, expect the price of the bond to fall and therefore suffer a negative capital gain (negative expected return on bonds) that is a capital loss. In this case, people would store their wealth as money because expected return of money (zero expected return) is higher than the expected return on bonds (negative) vice versa. According to Keynes, the demand for money is negatively related to the level of interest rates. Amount of money demanded on speculative-motive is a function of interestrate.

M2 $=\mathbf{L 2}(\mathbf{r})$

Where

M2 - Money demand on speculative-motive

L2 - Functional tendency, which fixes the quantity of money which the people willing to hold on speculative-motive

r - Nominal interest rate.

$\mathbf{M s}=\overline{\mathbf{M}}=\mathbf{L} 1(\mathbf{Y})+\mathbf{L 2}(\mathbf{r})$

People make a choice between money and bonds. The traditional money demand models hypothesize that the demand for real money balances is negatively related with the yield (interest rate) on financial assets such as treasury bills and bonds. The domestic interest rate represents the opportunity cost of holding money and public would prefer to hold more financial assets during times with higher interest rates. If agents in the market expect the nominal interest rate (the return on bonds) in the future to be lower than the current interest rate and then they 
reduce their holdings of money and increase their holdings of bonds. If the interest rates fall in the future, then the price of bonds increase and the agents have capital gain on the bonds they purchased previously on lower prices. This means that the demand for money in any period depends on both the current nominal interest rate and the expected future interest rate. If agents reduce the demand for money when increase the current nominal interest rate, it means that the demand for treasury bills in the financial market would be increased.

Many studies are available in the literature which estimates money demand function, using various time series econometrics methods. In the earlier stage, the studies employed the Ordinary Least Squares (OLS) method to estimate the money demand function and the Chow test to ascertain the stability of money demand. These studies do not take into account the time series properties and Chow test is low powered when the break point is unknown. Due to these reasons, studies in the earlier stage may have suffered from the spurious regression problem. The introduction of cointegration test has solved this problem, and many studies have employed this methodology to test the presence of stable long-run money demand function. The rationale is that if money demand and its determinants are co-integrated, this implies that the money demand function is stable as the cointegrated variables will never move too far apart, and will be attracted to their long-run equilibrium relationship. (Haghighat, 2011).

The study done by Hossain and Younus, (2009) investigates the sensitivity of money demand to interest rates on treasury bills in Bangladesh, using quarterly data for the period from quarter four in 1997 to quarter four in 2006. A standard money demand function is examined with real output and the interest rate on treasury bills. The result of the study shows that there is a wellbehaved and stable money demand function. The results have proved that the demand for money is sensitive to interest rate on treasury bills and relatively longer -maturity has given better results as they expected.
The study done by Gaurisankar (2012) using the data of Real GDP, Real Exchange Rate Lending Rate for the period $1981-2012$ to estimate the money demand function in Suriname has proved the significant positive relationship between Real Money Demand and Real GDP. The relationship between Real Money Demand and Interest Rate has taken negative value it is not statistically significant in the study. The study has used Cointegration method to analyses the log-run relationship among the series.

The study done by Sober Mall (2013) using Cointegration method also shows that there exist a positive significant relationship between Money demand and real income in the long run with Pakistan experiences. The study proved a negative relationship with interest rate. The real income and real exchange rate are the most significant factors of real demand for money according to the study.

The paper done by Hwang, (2002) shows that there exist a long term equilibrium relationship between demand for broad money (M2) and, its determinants; real income (Y/P) and long term interest rate in Korea. According to Hwang the long term interest rate is a better proxy to measure the opportunity cost of holding money, than short term interest rate.

Tahir (1995) described that among developing countries, it is accepted that interest rate is an unsatisfactory measure of the opportunity cost of holding money. First, financial markets have not well developed in the developing countries. Due to this situation in these countries, possibilities of substitution between money and other financial assets are limited. Secondly, a more practical objection is that the interest rates are often determined by the government and remain constant for long periods. There is no sufficient variation to enable its influence on the demand for money. However, according to Tahir's survey of theory and evidence with reference to Arab countries, in developing countries, interest rates are tools of development strategy rather than stabilization policy. Developing countries set 
their interest rates on financial assets below market equilibrium level, to stimulate investment and growth. The formulation of targets in economic and price stabilization and structural programs are constructed assuming existence of stable demand for money function. Tahir further described, Stability tests have found that the demand function is relatively stable over time. Such stability proved in the demand for money function indicates that effects in changes of money supply on other macroeconomic variables such as growth and price level are adequately predictable. Results of empirical studies on demand for money function in developing countries support this conclusion.

Mallikahewa (2014) in her study which has done using Co-integration methodology to find the effectiveness of interest rate channel of transmission mechanism of monetary policy shows a significant positive relationship between real money demand and interest rate in Sri Lankan experience. And she explains that it would be a results of existing a under developed financial market and less experiences of investments in financial assets. Sri Lankans are experienced to save money in fixed deposits with higher interest rates. It means that increase of interest rates leads increase in money supply.

\section{Study Questions:}

$\Delta$ Is the speculative component of money demand negatively linked with interest rate?

\section{Objective of the study:}

- To investigate the transaction motivation (income elasticity) and speculative motivations (interest rate elasticity) of the demand for money in the Sri Lankan context. The study expects the income elasticity should be positive and interest rate elasticity should be negative.

\section{Methods:}

The study investigates the Income elasticity and interest elasticity of money demand. Annual data in the period of $1977-2009$ are used for the study. All the data series that used for the study are non-stationary and, integrated of order one (I(1) series). If multiple individual time-series variables are non-stationary integrated of order one (I(1) series), Cointergration test is appropriate to determine whether there is a longterm relationship among the variables. Cointegration tests indicate the presence of such stable long-term relationships exists among the variables. Study employed a Cointergration test to determine whether there is a long-term relationship among the variables.

\section{Data Description:}

The sourcesof data are the Central Bank of Sri Lanka and International Financial Statistics (IFS) of International Monetary Fund. Demand for real Money Balances (RMd2) is used as indicators for money demand and $\mathrm{RMd} 2$ function is estimated on the income and interest rate. Central Bank Rate (CBR) is used as an indicator of short term interest rate and real gross domestic product at (RGDP) is used as income aggregate. The description of annually time series that used for this study is contained in the following Table 01 .

Table 01

\begin{tabular}{|l|l|l|l|l|}
\hline $\begin{array}{l}\text { Time series } \\
\text { of }\end{array}$ & $\begin{array}{l}\text { Denot } \\
\text { ation }\end{array}$ & Units & $\begin{array}{l}\text { Data } \\
\text { span }\end{array}$ & Note \\
\hline $\begin{array}{l}\text { Demand for } \\
\text { Real Money } \\
\text { Balancse } \\
\text { (RMd2) }\end{array}$ & RMd2 & Rs. Millions & $\begin{array}{l}1978- \\
2009\end{array}$ & $\begin{array}{l}\text { M2/CPI } \\
=R M d 2\end{array}$ \\
\hline $\begin{array}{l}\text { Real Gross } \\
\text { domestic } \\
\text { product (at } \\
\text { constant } \\
\text { price) }\end{array}$ & RGDP & Rs. Millions & $\begin{array}{l}1978- \\
\text { Annually }\end{array}$ & Annually \\
\hline $\begin{array}{l}\text { Central } \\
\text { bank rate }\end{array}$ & CBR & Base(2002) & & RGDP \\
\hline
\end{tabular}

VAR method does not capture non-linear elements that existing certainly in level variables ( RMd2, RGDP,) because a VAR is a linear model. The better way to respond to this problem is linearize the data by taking the logs of the levels. For this testing purpose, the original data were transformed to logarithms, and the transformation form and the new variables are 
described in the Table 2.

Table 02

\begin{tabular}{|l|l|l|l|l|}
\hline $\begin{array}{l}\text { Time series } \\
\text { of }\end{array}$ & $\begin{array}{l}\text { Denotat } \\
\text { ion }\end{array}$ & Units & $\begin{array}{l}\text { Data } \\
\text { span }\end{array}$ & Note \\
\hline $\begin{array}{l}\text { Log of } \\
\text { Demand for } \\
\text { Real Money } \\
\text { Balance } \\
\text { RMd2) }\end{array}$ & & $\begin{array}{l}\text { Rs. } \\
\text { Millions }\end{array}$ & $\begin{array}{l}1978- \\
2009\end{array}$ & $\begin{array}{l}\text { Annually } \\
\text { Log(RM } \\
\text { d2) }\end{array}$ \\
\hline $\begin{array}{l}\text { Log of Real } \\
\text { Gross LRGDP } \\
\text { domestic } \\
\text { product }\end{array}$ & $\begin{array}{l}\text { Rs. } \\
\text { Millions } \\
\text { Base(200 }\end{array}$ & $2009-$ & $\begin{array}{l}\text { Annually } \\
\text { Log(RG } \\
\text { Log of } \\
\text { Central bank } \\
\text { rate LCBR }\end{array}$ & $\%$ Per \\
\hline
\end{tabular}

\section{The Model}

The long run relationship between real money demand and other related endogenous variables is implied by the following equation. Income elasticity of money demand is expected to be positive and interest elasticity of money demand would be a negative value.

$$
\begin{aligned}
& L R M d 2=\varphi_{0}+\varphi_{1} L R G D P-\varphi_{2} L C B R+ \\
& \mu 3_{t-1}
\end{aligned}
$$

Where,

LRMd2 - Log of real money demand.

LRGDP - Log of real GDP

LCBR - Log of central Bank Rate

$\varphi_{0} \quad-$ Autonomous money demand

$\varphi_{1} \quad$ - Income elasticity of money demand (Expected to be positive)

$\varphi_{2} \quad$ - Interest rate elasticity of money demand (Expected to be negative)

$\varphi_{\mathrm{t}-1}$ - Deviation of money demand from the long run equilibrium in the previous year

\section{Hypothesis:}

Income elasticity is to be positive and interest elasticity is to be negative according to existing theories.

$$
H_{0}, \varphi_{1} \leq 0 \quad H_{1}, \varphi_{1}>0
$$

And

$$
H_{0}, \varphi_{2} \geq 0 \quad H_{1}, \varphi_{2}<0
$$

\section{Results}

\section{Unit root test}

When plotting the levels and differences of the three series the implication is that the data are non-stationary in levels, but stationary in differences. (See graph 01)

\section{Graph 01:}
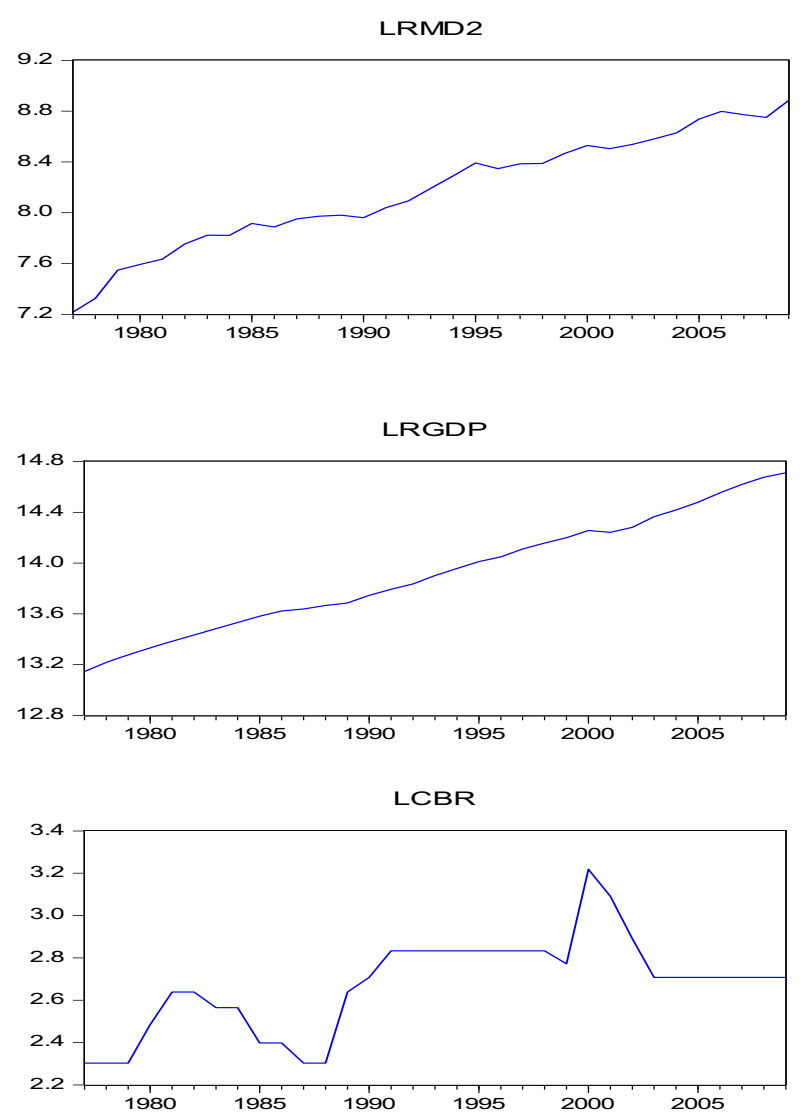

According to the Akaike information criterion (AIC) and Schwartz Bayesian criterion (SBC), the optimal lag length is selected as lag one and Stationarity of each series was tested using the Augmented Dicky Fuller (ADF) unit root test including a constant.Table 03 and table 04 report the results on $1 \%, 5 \%$ and $10 \%$ significant levels.According to this test, all variables are non-stationary. 
An Investigation on the Transaction Motivation and the Speculative Motivation of the Demand for Money in Sri Lanka

Table 03 - ADF test results (Level- Intercept)

\begin{tabular}{|l|l|l|l|l|}
\hline Variable & $\begin{array}{l}\text { ADF } \\
\text { Test } \\
\text { statistics }\end{array}$ & $\begin{array}{l}\text { Critical } \\
\text { values } \\
\mathbf{1 \%}\end{array}$ & $\begin{array}{l}\text { Critical } \\
\text { values } \\
\mathbf{5 \%}\end{array}$ & $\begin{array}{l}\text { Critical } \\
\text { values } \\
\mathbf{1 0 \%}\end{array}$ \\
\hline LRMd2 & -1.641173 & -3.6576 & -2.9591 & -2.6181 \\
\hline LRGDP & 0.465676 & -3.6576 & -2.9591 & -2.6181 \\
\hline LCBR & -2.322567 & -3.6576 & -2.9591 & -2.6181 \\
\hline
\end{tabular}

Table 04 - ADF test results ( $1^{\text {st }}$ difference- Intercept $)$

\begin{tabular}{|l|l|l|l|l|}
\hline Variable & $\begin{array}{l}\text { ADF } \\
\text { Test } \\
\text { statistics }\end{array}$ & $\begin{array}{l}\text { Critical } \\
\text { values } \\
\mathbf{1 \%}\end{array}$ & $\begin{array}{l}\text { Critical } \\
\text { values } \\
\mathbf{5 \%}\end{array}$ & $\begin{array}{l}\text { Critical } \\
\text { values } \\
\mathbf{1 0 \%}\end{array}$ \\
\hline LRMd2 & $-5.1448^{* *}$ & -3.6661 & -2.9627 & -2.6200 \\
\hline LRGDP & $-3.6249^{*}$ & -3.6661 & -2.9627 & -2.6200 \\
\hline LCBR & $-4.131461^{* *}$ & -3.6752 & -2.9665 & -2.622 \\
\hline
\end{tabular}

* denotes rejection of the hypothesis at the 0.05 level, and

** denotes rejection of the hypothesis at the 0.01 level

\section{Co-integration test:}

Likelihood statistics methodology is conducted to test whether there are any long run relationships among the above set of nonstationary variables. Since likelihood statistic of is 32.42 and it is larger than the critical value of 29.68 , the null hypothesis is rejected at the $5 \%$ significance level. This test confirmed that the variables are cointegrated and there is one cointegrating equation in the system. (at the 0.05 significant level)(see table 05)

Table 05

\begin{tabular}{|c|l|c|c|c|}
\hline $\begin{array}{l}\text { Hyphothes } \\
\text { ized No of } \\
\text { CE(s) }\end{array}$ & Eigen & $\begin{array}{c}\text { Likelihoo } \\
\mathbf{d} \\
\text { Ratio }\end{array}$ & $\begin{array}{c}\mathbf{5} \\
\text { Percent } \\
\text { Critical } \\
\text { value }\end{array}$ & $\begin{array}{c}\mathbf{1} \\
\text { Percent } \\
\text { Critical } \\
\text { value }\end{array}$ \\
\hline None * & 0.559636 & 32.42862 & 29.68 & 35.65 \\
\hline At most 1 & 0.195056 & 7.003853 & 15.41 & 20.04 \\
\hline At most 2 & 0.008908 & 0.277385 & 3.76 & 6.65 \\
\hline
\end{tabular}

* denotes rejection of the hypothesis at the 0.05 level

\section{Estimated Long Run Model; (Money Demand function)}

The long run equilibrium equation of money demand (LRMd2), which is estimated by the cointegration methodology, is given below. $\mathrm{T}$ values are given in the parentheses below.

$$
\begin{aligned}
& L R M d 2=-4.22+0.86 \mathrm{LRGDP}+ \\
& 0.16 \mathrm{LCBR}+\mu 3_{t-1} \\
& {[-24.8124] \quad[-2.79160]}
\end{aligned}
$$

\section{Conclusion}

In the long run model of money demand, interest rate (CBR) is positively related to real money balances $(\mathrm{RMd} 2)$. It means that interest rate elasticity of money demand is greater than zero and this coefficient is significant but inconsistent with the hypothesis. When the policy rate is increased, people would prefer to keep their money as savings and time deposits considering liquidity of money for transactions. They would not be attracted to financial assets such as bonds. The less developed financial market would be the reason for this inefficiency.

The elasticity of Real Gross Domestic Product (RGDP) is statistically highly significant and consistent in the long run money demand model. The estimated results show that the RGDP makes a powerful positive impact on the Real money demand. In the Sri Lankan context, demand for money is highly depended on transaction purpose. 


\section{References}

Gaurishankar, S. (2012), "The Money Demand Function in Suriname". 44 ${ }^{\text {th }}$ Annual Monetary Studies Conference, Paramaribo, Suriname.

Haghighat, J. (2011), "Real Money Demand, Income, and Interest Rates in Iran: Is there a Long- Run Stable Relation?" World Journal of Social Sciences Vol. 1. No. 2. May 2011 pp. $95-107$

Hossain, A. A. \& Younus, S. (2009), "Interest Rate and the Demand for Money in Bangladesh: An Empirical Investigation with Quarterly Data, 1997 Q4 - 2006 Q4". The IUP Journal ofMonetary Economics.

Hwang, J.K. (2002), "The Demand for Money in Korea: Evidence from the Co integration test". International Advance in Economic Research.

Keynes, J.M. (1936), "The general Theory of Employment, Interest and Money", eBook No.0300071h.html Col Choat colc@gutenberg.net.au

Mall, S. (2013), "Estimating a Function of Real Demand for Money in Pakistan: An Applicationof Bounds Testing Approach to Cointegration". International Journal of Computer Applications, Vol. 79, No. 5.

Mallikahewa, S.N.K (2014), "Effectiveness of Interest Rate Channel in the TransmissionMechanism of Monetary Policy in Sri Lanka”. Unpublished Monograhp. Sri Lanka

Mishkin, F.S.(2004), "Can Inflation Targeting work in Emerging Market Countries".Graduate School of Business. Colombia University, and NBER.

Mishkin, F.S. (2008), "Exchange Rate PassThrough and Monetary Policy." The Norges Bank Conference on Monetary Policy, Oslo, Norway.
Rao, B.B \& Singh, R., (2006), "Demand for Money in India: 1953-2003". 128.118.178.162/eps/mac/papers/0510/0510002 .pdf

Tahir, J. (1995), "Recent Development in Demand for Money Issues: Survey of Theory Evidence with Reference to Arab Countries". 